\title{
Early Sexual initiation among Adolescent Girls in Indonesia
}

\author{
Inisiasi Seksual Dini pada Remaja Perempuan di Indonesia
}

\author{
Aenaya Delavera*1 ${ }^{1}$, Tris Eryando ${ }^{2}$ \\ ${ }^{1,2}$ Bagian Kesehatan Masyarakat, Universitas Indonesia, Depok
}

DOI: 10.24252 al-sihah.v13i2.22404

Received: 26 July 2021 / In Reviewed: 13 December 2021 / Accepted: 26 December 2021 / Available online: 30 December 2021 CThe Authors 2021. This is an open access article under the CC BY-NC-SA 4.0 license

\begin{abstract}
Early sexual initiation is a public health problem and is now common worldwide, especially in developing countries. This can have many negative impacts on female adolescence, so it is very important to do prevention. This study aimed to determine the determinants of early sexual initiation among female adolescence in Indonesia. The subjects of the study were nevermarried women aged $15-24$. This research was quantitative using secondary data from the 2017 Indonesia Demographic and Health Survey (IDHS) with a cross-sectional research design. The results of the logistic regression showed that age, education, alcohol consumption, smoking, peer influence, boyfriend ownership, wealth, and media exposure were associated with early sexual initiation. Peer influence $(A O R=27,127 ; p<0.001)$ and education $(A O R=10,909 ; p=0.003)$ are the most dominant factors were associated with early sexual initiation. This study suggests the establishment of a comprehensive reproductive and sexual health (RSH) education mechanism both inside and outside schools; use the media to reach a wider range of youth, and programs to assist parents in optimizing their role in supervising adolescence.
\end{abstract}

\begin{abstract}
ABSTRAK
Inisiasi seksual dini merupakan masalah kesehatan masyarakat dan sekarang umum terjadi di seluruh dunia terutama di negara berkembang. Hal tersebut dapat memberikan banyaknya dampak negatif terlebih untuk remaja perempuan, sehingga sangat penting untuk dilakukan pencegahan. Penelitian ini bertujuan untuk mengetahui determinan inisiasi seksual dini pada remaja perempuan di Indonesia. Subjek penelitian adalah perempuan usia $15-24$ tahun yang belum pernah menikah. Penelitian ini bersifat kuantitatif menggunakan data sekunder Survei Demografi dan Kesehatan Indonesia (SDKI) 2017 dengan desain penelitian cross sectional. Hasil uji regresi logistik didapatkan bahwa usia, pendidikan, konsumsi alkohol, merokok, pengaruh teman sebaya, kepemilikan pacar, status ekonomi, dan paparan media informasi berhubungan dengan inisiasi seksual dini. Pengaruh teman sebaya $(\mathrm{AOR}=27,127 ; \mathrm{p}<0.001)$ dan pendidikan $(\mathrm{AOR}=10,909 ; \mathrm{p}=0.003)$ menjadi faktor yang paling dominan berhubungan dengan inisiasi seksual dini. Penelitian ini menyarankan kepada institusi pendidikan untuk dibuatnya mekanisme pendidikan kesehatan reproduksi dan seksual yang komprehensif baik di dalam maupun luar sekolah; BKKBN lebih memanfaatkan media agar dapat menjangkau remaja lebih luas; dan program GenRe Bina Keluarga Remaja (BKR) untuk membantu orang tua dalam mengoptimalkan perannya dalam mengawasi remaja.
\end{abstract}

\section{GRAPHICAL ABSTRACT}

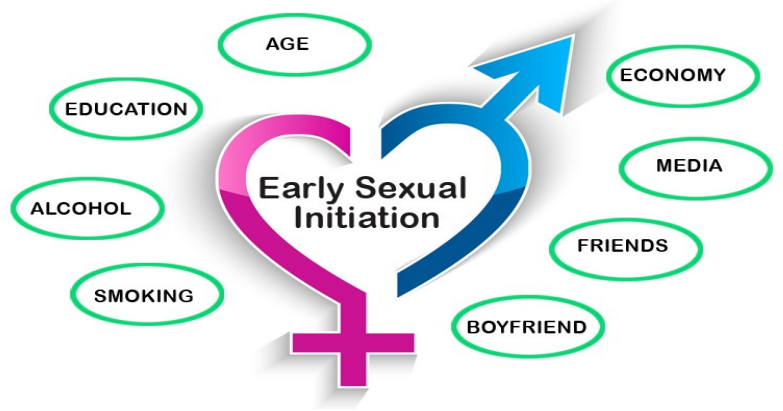

Keyword

determinants; early sexual initiation; female adolescents; indonesian adolescents

Kata Kunci:

determinan; inisiasi seksual dini; remaja indonesia; remaja perempuan

* Correspondence

Jl. Panti Asuhan RT.02/012 No. 58, Jurangmangu Timur, Tangerang Selatan, Banten 15222

Email: aenaya.delavera@alumni.ui.ac.id 


\section{PENDAHULUAN}

Masa remaja adalah masa kritis pada tahap transisi individu dalam kesehatan, perkembangan sosial dan kesejahteraan dari masa kanak-kanak hingga dewasa (Rizkianti et al., 2020). Remaja merupakan sumber daya terbesar bagi masyarakat untuk berkembang (World Health Organization, 2017). Pada tahun 2017 terdapat 1,2 miliar remaja berusia 15 - 24 tahun, yang merupakan $16 \%$ dari populasi global. Angka tersebut diproyeksikan akan tumbuh menjadi $23 \%$ di tahun 2030 menjadi 1,3 miliar (United Nations, 2018). Penduduk remaja usia 15-24 tahun merupakan sekitar 17\% dari jumlah penduduk Indonesia dan dari hasil proyeksi penduduk akan terus meningkat. Dengan demikian, pemerintah memiliki peluang untuk memanfaatkan bonus demografis untuk mencapai tujuan pembangunan nasional. Meskipun demikian, remaja juga merupakan kelompok rentan, khususnya di bidang kesehatan seksual dan reproduksi. Remaja yang belum sepenuhnya mengembangkan kapasitas mereka untuk pengendalian diri, lebih cenderung membuat keputusan dengan sedikit pemikiran atau perencanaan. Remaja yang lebih impulsif mungkin lebih tinggi kemungkinannya untuk melakukan perilaku berisiko, seperti memulai seks pada usia dini (Project SOAR, 2021).

Inisiasi seksual dini merupakan masalah kesehatan masyarakat dan sekarang umum terjadi di seluruh dunia terutama di negara berkembang (Yosef et al., 2020). Meskipun tidak ada definisi universal tentang inisiasi seksual dini, hal ini sering didefinisikan sebagai hubungan seksual selama sekolah menengah atau hubungan seksual sebelum usia legal (Pringle et al., 2017); melakukan hubungan seks vaginal untuk pertama kalinya pada usia 14 tahun atau lebih muda (Lee et al., 2017); dan pengalaman melakukan hubungan seksual pertama kali sebelum usia 18 tahun (Arefaynie et al., 2020; Turi et al., 2020; Yosef et al., 2020). Sedangkan di Indonesia, Badan Kependudukan dan Keluarga Berencana Nasiona memiliki program pendewasaan usia perkawinan (PUP) dimana usia minimal seorang perempuan menikah usia 21 tahun dan laki-laki 25 tahun. Batasan usia tersebut dianggap sudah siap menghadapi kehidupan keluarga dan praktek seksual dipandang dari sisi kesehatan dan perkembangan emosional (Dini \& Nurhelita, 2020). Maka mengacu pada hal tersebut, inisiasi seksual dini di Indonesia dapat diartikan sebagai melakukan hubungan seksual pertama kali saat usia di bawah 21 tahun.

Prevalensi remaja perempuan yang melakukan inisiasi seksual dini pada penelitian di Ethiopia bervariasi diantaranya 18,4\% (Kassahun et al., 2019); 38,4\% (Abate et al., 2020); 21,4\% (Turi et al., 2020); dan 20,4\% (Bizu et al., 2015). Penelitian di Thailand menunjukkan bahwa inisiasi seksual dini remaja perempuan usia 15-19 tahun sebesar 11\% (Techasrivichien et al., 2016). Kemudian penelitian di Philipina, remaja perempuan yang melakukan inisiasi seksual dini didapatkan meningkat dari tahun ke tahun, yaitu 10,5\% pada tahun 2003; $13,6 \%$ pada tahun 2008 ; dan $14,6 \%$ pada tahun 2013 (Habitoet al., 2019).

Di Indonesia sendiri, salah satu penelitian di Kalimantan Tengah menunjuk- 
kan bahwa remaja yang tinggal di perkotaan memiliki kemungkinan 3,47 kali untuk melakukan perilaku seksual pranikah dan yang bersekolah di SMA ke atas memiliki kemungkinan 2,71 kali untuk melakukan perilaku seksual pranikah (Citrariana et al., 2021). Menurut data Riset Kesehatan Dasar pada tahun 2010, inisiasi seksual dini terjadi sebanyak $1 \%$ pada remaja laki-laki dan 4\% pada anak remaja perempuan di seluruh Indonesia. Walaupun prevalensi di Indonesia terlihat jauh lebih sedikit dibandingkan dengan negara-negara lain, namun perkiraan tentang perilaku seksual memang sangat sulit diperediksi dan perkiraan angka di Indonesia mungkin cenderung bukanlah keadaan yang sebenarnya. Hal tersebut tentu dikarenakan adanya ketidaksetujuan sosial dan privasi pribadi (King, 2019). Terlebih untuk remaja perempuan, mereka tentunya akan lebih merasa takut akan dihakimi orang lain karena melakukan hubungan seksual pranikah dan dicap sebagai wanita yang tidak baik. Ketakutan ini juga berakar pada latar belakang budaya-agama dari komunitas, yang sangat jelas melarang hubungan seksual pranikah (Mohammadi et al., 2016).

Padahal data merupakan hal yang sangat penting dalam bidang kesehatan masyarakat. Data dapat digunakan untuk mengevaluasi dampak program, untuk menentukan intervensi kesehatan masyarakat yang tepat, untuk memantau kemajuan, untuk menentukan populasi yang menjadi sasaran intervensi, untuk menentukan hambatan perawatan, dan untuk mempengaruhi kebijakan publik. Dari sebuah data, kita bisa lebih mudah menentukan apakah ma- salah tersebut perlu menjadi prioritas atau tidak. Ketika angka inisiasi seksual dini pada remaja perempuan di Indonesia yang tercatat sedikit, maka permasalahan tersebut akan cenderung tak terlihat. Sehingga berujung pada upaya yang juga minim.

Inisiasi seksual dini memiliki dampak negatif dalam segi kesehatan, sosial dan konsekuensi ekonomi bagi perempuan dan generasi mendatang. Itu adalah faktor risiko untuk kehamilan yang tidak diinginkan pada remaja, masalah mental, kemungkinan memiliki multiple partner sehingga meningkatkan risiko penyakit menular seksual seperti HIV / AIDS, hingga kematian ibu dan anak. Hal ini juga meningkatkan risiko putus sekolah, stigma dan diskriminasi di masyarakat (UNFPA, 2017; Arefaynie et al., 2020). Oleh karena itu, inisiasi seksual dini ini juga perlu diperhatikan untuk kesehatan dan kesejahteraan remaja di masa mendatang.

Menurut model sosio-ekologi Bronfenbrenner terdapat faktor-faktor pada tingkatan berbeda yang mempengaruhi suatu perilaku. Faktor tersebut terdiri dari faktor individu, faktor interpersonal, dan faktor lingkungan (Adamek et al., 2020). Dengan demikian, faktor yang berpengaruh terhadap kejadian inisiasi seksual dini terdiri dari tiga, yaitu faktor individu (usia, pendidikan, pengetahuan, konsumsi alkohol, penggunaan narkoba, dan merokok), faktor interpersonal (komunikasi dengan orang tua, pengaruh teman sebaya, dan kepemilikan pacar), dan faktor lingkungan (tempat tinggal, status ekonomi, paparan media informasi, dan program kesehatan reproduksi dan seksual) (Bizu et al., 2015; 
Abate et al., 2020; Adamek et al., 2020).

Salah satu upaya pencegahan kehamilan dini dan berbagai outcome masalah kesehatan reproduksi lainnya pada remaja perempuan di negara berkembang adalah mencegah inisiasi seksual dini (WHO \& UNFPA, 2012). Maka dari itu, tujuan penelitian ini adalah untuk mengetahui determinan dari inisiasi seksual dini agar upaya pencegahan dapat dilakukan dengan efektif. Selain itu, penelitian ini dilakukan karena di Indonesia sendiri walaupun sudah banyak penelitian mengenai seks pranikah, tetapi data nasional mengenai inisiasi seksual dini di kalangan remaja perempuan masih sangat terbatas. Sehingga kemudian penelitian ini dapat menyumbang data nasional mengenai inisiasi seksual dini. Penelitian dilakukan menggunakan data Survei Demografi Kesehatan Indonesia (SDKI) dengan sampel yang dinilai representatif mewakili populasi remaja perempuan di Indonesia. Variabel yang diteliti juga sudah termasuk dari tingkatan individu hingga lingkungan, sehingga dapat melihat secara menyeluruh dalam mengambil keputusan untuk keberlanjutan program kesehatan reproduksi di Indonesia.

\section{METODE PENELITIAN}

Penelitian ini merupakan penelitian kuantitatif yang menggunakan data sekunder SDKI 2017 dengan desain studi cross sectional. Penelitian dilakukan di Indonesia pada bulan Februari sampai Juni 2021. Subjek penelitian adalah remaja perempuan usia 15 - 24 tahun yang belum pernah menikah di Indonesia. Kriteria inklusi sampel adalah remaja perempuan belum pernah menikah berusia 15 - 24 tahun, termasuk yang pernah tinggal bersama; dan memiliki data lengkap terkait variabel yang akan diteliti. Menggunakan teknik total sampling dengan menggunakan keseluruhan sampel yang memenuhi kriteria dalam data SDKI 2017 yaitu sebanyak 10.467 individu. Penelitian ini telah melalui prosedur kaji etik dan dinyatakan lolos etik oleh Komisi Etik Riset dan Pengabdian Kesehatan Masyarakat FKM UI dengan Nomor:

Ket-145/UN2.F10.D11/ PPM.00.02/2021.

Analisis menggunakan complex sample design untuk mendapatkan hasil yang lebih representatif karena survei tidak dilakukan dengan simple random sampling. Analisis data yang digunakan adalah analisis univariat menggunakan statistik deskriptif untuk melihat distribusi frekuensi dan persentase karakteristik responden, analisis bivariat menggunakan crosstab untuk melihat hubungan antara variabel independen dengan dependen, dan analisis multivariat menggunakan regresi logistik untuk menguji secara bersamaan hubungan beberapa variabel independen dengan satu variabel dependen.

Variabel dependen dalam penelitian ini adalah inisiasi seksual dini yang didefinisikan sebagai pengalaman memulai hubungan seksual pertama kali sebelum 21 tahun. Variabel independen yang diteliti adalah faktor individu (usia, pendidikan, konsumsi alkohol, penggunaan narkoba, merokok), faktor interpersonal (komunikasi dengan orangtua, pengaruh teman sebaya, kepemilikan pacar), dan faktor lingkungan (tempat tinggal, status ekonomi, paparan 
Tabel 1

Distribusi Frekuensi Karakteristik Responden

\begin{tabular}{|c|c|c|}
\hline Kategori & Frekuensi & Persentasi $(\%)$ \\
\hline \multicolumn{3}{|l|}{ Inisiasi Seksual Dini } \\
\hline Tidak & 10.303 & 98.94 \\
\hline Ya & 164 & 1.06 \\
\hline \multicolumn{3}{|l|}{ Usia } \\
\hline 15-19 tahun & 7.071 & 67.9 \\
\hline 20-24 tahun & 3.396 & 32.1 \\
\hline \multicolumn{3}{|l|}{ Pendidikan } \\
\hline Tinggi & 2.729 & 23.85 \\
\hline Menengah & 7.335 & 72.5 \\
\hline Dasar & 371 & 3.37 \\
\hline Tidak Bersekolah & 32 & 0.28 \\
\hline \multicolumn{3}{|l|}{ Konsumsi Alkohol } \\
\hline Tidak & 10.311 & 99.05 \\
\hline Ya & 156 & 0.95 \\
\hline \multicolumn{3}{|l|}{ Penggunaan Narkoba } \\
\hline Tidak & 10.447 & 99.84 \\
\hline Ya & 20 & 0.16 \\
\hline \multicolumn{3}{|l|}{ Merokok } \\
\hline Tidak & 9.574 & 92.85 \\
\hline Ya & 893 & 7.15 \\
\hline \multicolumn{3}{|l|}{ Komunikasi dengan Orangtua } \\
\hline $\mathrm{Ya}$ & 5.312 & 53.13 \\
\hline Tidak & 5.155 & 46.81 \\
\hline \multicolumn{3}{|l|}{ Pengaruh Teman Sebaya } \\
\hline Tidak & 10.225 & 98.19 \\
\hline Ya & 242 & 1.81 \\
\hline \multicolumn{3}{|l|}{ Kepemilikan Pacar } \\
\hline Tidak & 5.434 & 52.2 \\
\hline $\mathrm{Ya}$ & 5.033 & 47.8 \\
\hline \multicolumn{3}{|l|}{ Tempat Tinggal } \\
\hline Perkotaan & 6.239 & 58.79 \\
\hline Pedesaan & 4.228 & 41.21 \\
\hline \multicolumn{3}{|l|}{ Status Ekonomi } \\
\hline Teratas & 2.456 & 26.69 \\
\hline Menengah Atas & 2.105 & 21.63 \\
\hline Menengah & 1.954 & 19.66 \\
\hline Menengah Bawah & 1.95 & 17.79 \\
\hline Terbawah & 2.002 & 14.23 \\
\hline \multicolumn{3}{|l|}{ Paparan Media } \\
\hline Terpapar & 9.385 & 90.45 \\
\hline Tidak Terpapar & 1.082 & 9.55 \\
\hline \multicolumn{3}{|c|}{ Program Kespro dan Seksual (Sekolah) } \\
\hline Berperan & 5.357 & 54.18 \\
\hline Tidak Berperan & 5.11 & 45.82 \\
\hline \multicolumn{3}{|c|}{ Program Kespro dan Seksual (Komunitas) } \\
\hline Ya & 1.179 & 11.11 \\
\hline Tidak & 9.288 & 88.89 \\
\hline \multicolumn{3}{|c|}{ Program Kespro dan Seksual (Tempat Ramah Remaja) } \\
\hline Ya & 415 & 4.42 \\
\hline Tidak & 10.052 & 95.58 \\
\hline
\end{tabular}


Tabel 2

Hubungan Faktor Individu dengan Inisiasi Seksual Dini

\begin{tabular}{|c|c|c|c|c|c|c|c|c|}
\hline \multirow{3}{*}{ Variabel } & \multicolumn{4}{|c|}{ Inisiasi Seksual Dini } & \multirow{2}{*}{\multicolumn{2}{|c|}{ Total }} & \multirow{3}{*}{ OR $(95 \% \mathrm{CI})$} & \multirow{3}{*}{ P-Value } \\
\hline & \multicolumn{2}{|c|}{ Tidak } & \multicolumn{2}{|c|}{$\mathrm{Ya}$} & & & & \\
\hline & $\mathrm{n}$ & $\%$ & $\mathrm{n}$ & $\%$ & $\mathrm{n}$ & $\%$ & & \\
\hline \multicolumn{9}{|l|}{ Usia } \\
\hline 15-19 tahun & 6.996 & 99,23 & 75 & 0,77 & 7.071 & 100,00 & (Reference) & $<0.001$ \\
\hline 20-24 tahun & 3.307 & 98,33 & 89 & 1,67 & 3.396 & 100,00 & $2.20(1.49-3.24)$ & \\
\hline \multicolumn{9}{|l|}{ Pendidikan } \\
\hline Tinggi & 2.691 & 99,10 & 38 & 0,90 & 2.729 & 100,00 & (Reference) & \\
\hline Menengah & 7.227 & 99,02 & 108 & 0,98 & 7.335 & 100,00 & $1.09(0.06-1.82)$ & $<0.001$ \\
\hline Dasar & 355 & 96,57 & 16 & 3,43 & 371 & 100,00 & $3.92(1.82-8.41)$ & \\
\hline Tidak Bersekolah & 30 & 93,13 & 2 & 6,87 & 32 & 100,00 & $8.15(1.72-38.5)$ & \\
\hline \multicolumn{9}{|l|}{ Konsumsi Alkohol } \\
\hline Tidak & 10.163 & 99,07 & 148 & 0,93 & 10.311 & 100,00 & (Reference) & $<0.001$ \\
\hline $\mathrm{Ya}$ & 140 & 85,52 & 16 & 14,48 & 156 & 100,00 & $18.06(8.77-37.16)$ & \\
\hline \multicolumn{9}{|l|}{ Penggunaan Narkoba } \\
\hline Tidak & 10.315 & 98,96 & 162 & 1,04 & 10.447 & 100,00 & (Reference) & 0.0013 \\
\hline $\mathrm{Ya}$ & 18 & 85,84 & 2 & 14,16 & 20 & 100,00 & $15.75(2.95-84.07)$ & \\
\hline \multicolumn{9}{|l|}{ Merokok } \\
\hline Tidak & 9.459 & 99,22 & 115 & 0,78 & 9.574 & 100,00 & (Reference) & $<0.001$ \\
\hline Ya & 844 & 95,36 & 49 & 4,64 & 893 & 100,00 & $6.16(3.90-9.73)$ & \\
\hline
\end{tabular}

media, dan program kesehatan reproduksi \& seksual di sekolah, komunitas maupun tempat ramah remaja).

\section{HASIL PENELITIAN}

Karakteristik responden dalam penelitian ini disajikan pada tabel 1. Proporsi inisiasi seksual dini pada remaja perempuan di Indonesia tahun 2017 sebesar $1.06 \%$. Berdasarkan faktor individu, mayoritas berusia 15 - 19 tahun $(67.90 \%)$, berpendidikan menengah (SMA) $(72.50 \%)$, tidak pernah mengkonsumsi alkohol (99.05\%), tidak pernah menggunakan narkoba $(99.84 \%)$, dan tidak pernah merokok $(92.85 \%)$. Berdasarkan faktor interpersonal, responden lebih banyak yang berkomunikasi dengan salah satu atau kedua orang tuanya dalam membicarakan kesehatan reproduksi (53.19\%), tidak mendapat pengaruh dari teman sebaya untuk melakukan inisiasi seksual dini (98.19\%), dan tidak memiliki pacar (52.20\%). Kemudian berdasarkan faktor lingkungan, responden lebih banyak yang tinggal di perkotaan (58.79\%), memiliki status ekonomi teratas $(26.69 \%)$, terpapar media mengenai kespro $(90.45 \%)$, memiliki sekolah yang berperan dalam edukasi kespro (54.18\%), tidak pernah menghadiri pertemuan komunitas mengenai kespro (88.89\%), dan tidak pernah mengunjungi tempat ramah remaja untuk memperoleh edukasi dan konseling mengenai kespro (95.58\%).

Tabel 2 menunjukkan hubungan antara faktor individu dengan inisiasi seksual dini. Didapatkan hasil bahwa terdapat hub- 
Tabel 3

Hubungan Faktor Interpersonal dengan Inisiasi Seksual Dini

\begin{tabular}{|c|c|c|c|c|c|c|c|c|}
\hline \multirow{3}{*}{ Variabel } & \multicolumn{4}{|c|}{ Inisiasi Seksual Dini } & \multirow{2}{*}{\multicolumn{2}{|c|}{ Total }} & \multirow{3}{*}{ OR $(95 \% \mathrm{CI})$} & \multirow{3}{*}{ P-Value } \\
\hline & \multicolumn{2}{|c|}{ Tidak } & \multicolumn{2}{|c|}{$\mathrm{Ya}$} & & & & \\
\hline & $\mathrm{n}$ & $\%$ & $\mathrm{n}$ & $\%$ & $\mathrm{n}$ & $\%$ & & \\
\hline \multicolumn{9}{|c|}{ Komunikasi dengan Orang Tua } \\
\hline $\mathrm{Ya}$ & 5.239 & 99,09 & 73 & 0,91 & 5.312 & 100,00 & (Reference) & 0.1546 \\
\hline Tidak & 5.064 & 98,78 & 91 & 1,22 & 5.155 & 100,00 & $1.33(0.89-2.00)$ & \\
\hline \multicolumn{9}{|c|}{ Pengaruh Teman Sebaya } \\
\hline Tidak & 10.127 & 99,34 & 98 & 0,66 & 10.225 & 100,00 & (Reference) & $<0.001$ \\
\hline Ya & 176 & 77,35 & 66 & 22,65 & 242 & 100,00 & $44.15(27.28-71.44$ & \\
\hline \multicolumn{9}{|l|}{ Kepemilikan Pacar } \\
\hline Tidak & 5.405 & 99,61 & 29 & 0,39 & 5.434 & 100,00 & (Reference) & $<0.001$ \\
\hline Ya & 4.898 & 98,21 & 235 & 1,79 & 5.033 & 100,00 & $4.63(2.65-8.08)$ & \\
\hline
\end{tabular}

ungan yang bermakna antara usia, pendidikan, konsumsi alkohol, penggunaan narkoba, dan merokok $(\mathrm{p}<0.05)$. Nilai OR pada remaja perempuan usia $20-24$ tahun sebesar $2.20(95 \%$ CI $=1.49-3.24)$ yang artinya remaja perempuan usia $20-24$ tahun memiliki risiko 2.2 kali lebih besar untuk melakukan inisiasi seksual dini dibandingkan remaja perempuan usia 15 19 tahun. Nilai OR pada remaja perempuan yang tidak bersekolah sebesar 8.15 (95\% $\mathrm{CI}=1.72-38.5)$ yang artinya remaja perempuan yang tidak bersekolah memiliki risiko 8.15 kali lebih besar untuk melakukan inisiasi seksual dini dibandingkan remaja yang berpendidikan tinggi. Nilai OR pada remaja perempuan yang mengonsumsi alkohol sebesar 18.06 (95\% $\mathrm{CI}=8.77-37.16)$ yang artinya remaja perempuan yang mengonsumsi alkohol memiliki risiko 18.06 kali lebih besar untuk melakukan inisiasi seksual dini dibandingkan remaja perempuan yang tidak mengonsumsi alkohol. Nilai OR pada remaja perempuan yang menggunakan narkoba sebesar $15.75(95 \% \mathrm{CI}=2.95-84.07)$ yang artinya remaja perempuan yang menggunakan narkoba memiliki risiko 15.75 kali lebih besar untuk melakukan inisiasi seksual dini dibandingkan remaja perempuan yang tidak menggunakan narkoba. Nilai OR pada remaja perempuan yang merokok sebesar 6.16 (95\% CI $=3.90-$ 9.73) yang artinya remaja perempuan yang merokok memiliki risiko 6.16 kali lebih besar untuk melakukan inisiasi seksual dini dibandingkan remaja yang tidak merokok.

Tabel 3 menunjukkan hubungan antara faktor interpersonal dengan inisiasi seksual dini. Didapatkan hasil bahwa terdapat hubungan antara pengaruh teman sebaya dan kepemilikan pacar dengan inisiasi seksual dini $(p<0.05)$. Nilai OR pada remaja perempuan yang mendapat dorongan atau motivasi dari teman sebaya sebesar $44.15(95 \% \mathrm{CI}=27.28-71.44)$ yang artinya remaja perempuan yang mendapat dorongan atau motivasi dari teman sebaya memiliki risiko 44.15 kali lebih besar untuk melakukan inisiasi seksual dini dibandingkan dengan remaja perempuan yang tidak mendapat dorongan 
Tabel 4

Hubungan Faktor Lingkungan dengan Inisiasi Seksual Dini

\begin{tabular}{|c|c|c|c|c|c|c|c|c|}
\hline \multirow{3}{*}{ Faktor Lingkungan } & \multicolumn{4}{|c|}{ Inisiasi Seksual Dini } & \multirow{2}{*}{\multicolumn{2}{|c|}{ Total }} & \multirow{3}{*}{ OR $(95 \% \mathrm{CI})$} & \multirow{3}{*}{$\begin{array}{c}\text { P- } \\
\text { Value }\end{array}$} \\
\hline & \multicolumn{2}{|c|}{ Tidak } & \multicolumn{2}{|c|}{$\mathrm{Ya}$} & & & & \\
\hline & $\mathrm{n}$ & $\%$ & $\mathrm{n}$ & $\%$ & $\mathrm{n}$ & $\%$ & & \\
\hline \multicolumn{9}{|l|}{ Tempat Tinggal } \\
\hline Perkotaan & 6.155 & 98,93 & 84 & 1,07 & 6.239 & 100,00 & (Reference) & 0.9305 \\
\hline Pedesaan & 4.148 & 98,95 & 80 & 1,05 & 4.228 & 100,00 & $0.98(0.63-1.51)$ & \\
\hline \multicolumn{9}{|l|}{ Status Ekonomi } \\
\hline Teratas & 2.438 & 99,42 & 18 & 0,58 & 2.456 & 100,00 & (Reference) & \\
\hline Menengah Atas & 2.078 & 98,76 & 27 & 1,24 & 2.105 & 100,00 & $2.14(0.99-4.61)$ & $<0.001$ \\
\hline Menengah & 1.935 & 99,39 & 19 & 0,61 & 1.954 & 100,00 & $1.04(0.42-2.59)$ & \\
\hline Menengah Bawah & 1.92 & 99,13 & 30 & 0,87 & 1.95 & 100,00 & $1.50(0.66-3.40)$ & \\
\hline Terbawah & 1.932 & 97,48 & 70 & 2,52 & 2.002 & 100,00 & $4.40(2.14-9.05)$ & \\
\hline \multicolumn{9}{|l|}{ Paparan Media } \\
\hline Terpapar & 9.249 & 99,02 & 136 & 0,98 & 9.385 & 100,00 & (Reference) & 0.0302 \\
\hline Tidak Terpapar & 1.054 & 98,24 & 28 & 2,76 & 1.082 & 100,00 & $1.80(1.05-3.09)$ & \\
\hline \multicolumn{9}{|l|}{$\begin{array}{l}\text { Program Kespro dan Sek- } \\
\text { sual (Sekolah) }\end{array}$} \\
\hline Berperan & 5.291 & 99,08 & 66 & 0,92 & 5.357 & 100,00 & (Reference) & 0.2088 \\
\hline Tidak Berperan & 5.012 & 98,78 & 98 & 1,22 & 5.11 & 100,00 & $1.33(0.84-2.11)$ & \\
\hline \multicolumn{9}{|l|}{$\begin{array}{l}\text { Program Kespro dan Sek- } \\
\text { sual (Komunitas) }\end{array}$} \\
\hline $\mathrm{Ya}$ & 1.161 & 99,02 & 18 & 0,98 & 1.179 & 100,00 & (Reference) & 0.8291 \\
\hline Tidak & 9.142 & 98,93 & 146 & 1,07 & 9.288 & 100,00 & $1.09(0.47-2.51)$ & \\
\hline \multicolumn{9}{|l|}{$\begin{array}{l}\text { Program Kespro dan Sek- } \\
\text { sual (T. Ramah Remaja) }\end{array}$} \\
\hline $\mathrm{Ya}$ & 409 & 99,16 & 6 & 0,84 & 415 & 100,00 & (Reference) & 0.6735 \\
\hline Tidak & 9.894 & 98,93 & 158 & 1,07 & 10.052 & 100,00 & $1.27(0.41-3.91)$ & \\
\hline
\end{tabular}

atau motivasi dari teman sebaya. Nilai OR pada remaja perempuan yang memiliki pacar adalah $4.63(95 \% \mathrm{CI}=2.65-8.08)$ yang artinya remaja perempuan yang memiliki pacar memiliki risiko 4.63 kali lebih besar untuk melakukan inisiasi seksual dini dibandingkan remaja yang tidak memiliki pacar.

Tabel 4 menunjukkan hubungan antara faktor lingkungan dengan inisiasi seksual dini. Didapatkan hasil bahwa terdapat hubungan antara status ekonomi dan paparan media dengan inisiasi seksual dini $(p<0.05)$. Remaja perempuan yang memiliki status ekonomi terbawah memiliki OR sebesar $4.40(95 \%$ CI $=2.14-9.05)$ yang artinya remaja perempuan berstatus ekonomi terbawah memiliki risiko 4.40 kali lebih besar untuk melakukan inisiasi seksual dini dibandingkan dengan remaja perempuan berstatus ekonomi teratas. Nilai OR pada remaja perempuan yang tidak terpapar me- 
Tabel 5

Model Determinan Inisiasi Seksual Dini

\begin{tabular}{|c|c|c|c|c|}
\hline Variabel & SE & P-Value & AOR & $95 \% \mathrm{CI}$ \\
\hline \multicolumn{5}{|l|}{ Usia } \\
\hline 15-19 tahun & & & $1^{*}$ & \\
\hline 20-24 tahun & 0,565 & 0,017 & 1,980 & $1,131-3,467$ \\
\hline \multicolumn{5}{|l|}{ Pendidikan } \\
\hline Tinggi & & & $1^{*}$ & \\
\hline Menengah & 0,599 & 0,180 & 1,634 & $0,796-3,354$ \\
\hline Dasar & 2,637 & 0,001 & 5,190 & $1,915-14,062$ \\
\hline Tidak Bersekolah & 8,892 & 0,003 & 10,909 & $2,205-53,962$ \\
\hline \multicolumn{5}{|l|}{ Konsumsi Alkohol } \\
\hline Tidak & & & $1^{*}$ & \\
\hline$\underline{\mathrm{Ya}}$ & 3,157 & 0,000 & 6,684 & $2,646-16,882$ \\
\hline \multicolumn{5}{|l|}{ Merokok } \\
\hline Tidak & & & $1^{*}$ & \\
\hline $\mathrm{Ya}$ & 0,723 & 0,000 & 2,697 & $1,593-4,566$ \\
\hline \multicolumn{5}{|l|}{ Pengaruh Teman Sebaya } \\
\hline Tidak & & & $1^{*}$ & \\
\hline Ya & 7,452 & 0,000 & 27,127 & $15,827-46,495$ \\
\hline \multicolumn{5}{|l|}{ Kepemilikan Pacar } \\
\hline Tidak & & & $1^{*}$ & \\
\hline Ya & 1,069 & 0,000 & 3,373 & $1,811-6,283$ \\
\hline \multicolumn{5}{|l|}{ Status Ekonomi } \\
\hline Teratas & & & $1^{*}$ & \\
\hline Menengah Atas & 0,894 & 0,180 & 1,887 & $0,745-4,778$ \\
\hline Menengah & 0,515 & 0,948 & 1,033 & $0,388-2,751$ \\
\hline Menengah Bawah & 0,751 & 0,280 & 1,640 & $0,667-4,029$ \\
\hline Terbawah & 1,440 & 0,002 & 4,519 & $1,577-7,854$ \\
\hline \multicolumn{5}{|l|}{ Paparan Media } \\
\hline Terpapar & & & $1^{*}$ & \\
\hline Tidak Terpapar & 0,554 & 0,017 & 1,678 & $0,877-3,208$ \\
\hline
\end{tabular}

dia sebesar $1.80(95 \% \mathrm{CI}=1.05-3.09)$ yang artinya remaja perempuan yang tidak terpapar media memiliki risiko 1.80 lebih besar untuk melakukan inisiasi seksual dini dibandingkan remaja yang terpapar media.

Tabel 5 menunjukkan hasil regresi logistik bahwa variabel independen yang signifikan berhubungan dengan inisiasi seksual dini pada remaja perempuan di Indonesia adalah variabel usia, pendidikan, konsumsi alkohol, merokok, pengaruh teman sebaya, kepemilikan pacar, tempat tinggal, status ekonomi, dan paparan me- dia. Dari beberapa variabel tersebut, variabel yang sangat dominan berhubungan dengan inisiasi seksual dini yaitu variabel pengaruh teman sebaya dan pendidikan. Pada variabel pengaruh teman sebaya, remaja perempuan yang mendapat dorongan atau motivasi dari teman sebaya memiliki AOR sebesar 27,127 (95\% CI = 15,827 - 46,495) yang artinya remaja perempuan yang mendapat dorongan atau motivasi dari teman sebaya memiliki risiko 27,127 kali lebih besar untuk melakukan inisiasi seksual dini dibandingkan remaja 
perempuan yang tidak mendapat dorongan atau motivasi dari teman sebaya setelah dikontrol oleh variabel independen lain. Remaja perempuan yang tidak bersekolah memiliki AOR sebesar 10,909 $(95 \%$ CI = 2,205 - 53,962) yang artinya remaja perempuan yang tidak bersekolah memiliki risiko 10,909 kali lebih besar untuk melakukan inisiasi seksual dini dibandingkan remaja perempuan yang berpendidikan tinggi setelah dikontrol oleh variabel independen lain.

\section{PEMBAHASAN}

Usia memiliki hubungan bermakna dengan inisiasi seksual dini, dan hal tersebut sejalan dengan penelitian Abate et al. (2020). Remaja perempuan usia 20 - 24 tahun saat wawancara cenderung pernah melakukan inisiasi seksual dini dibandingkan remaja perempuan usia 15 - 19 tahun. Hal ini mungkin terjadi karena remaja usia 20-24 tahun sudah melewati fase usia 15-19 tahunnya, sehingga akan lebih banyak kasus yang tertangkap dibandingkan kasus pada remaja 15-19 tahun. Sedangkan untuk remaja 15-19 tahun, misal mereka yang berusia 15 tahun mengaku belum pernah melakukan hubungan seks saat waktu wawancara. Namun tidak diketahui kemungkinan remaja itu saat usia 16 keatas melakukan seks dini atau tidak; jadi dalam hal ini, kasus tidak tertangkap. Selain itu, perbedaan kedua kelompok tersebut mungkin bisa disebabkan oleh peningkatan pelayanan kesehatan ramah remaja dari waktu ke waktu yang dapat meningkatkan pengetahuan, kepercayaan diri dalam mencegah masalah seksual lainnya (Arefaynie et al., 2020).
Pendidikan memiliki hubungan bermakna dengan inisiasi seksual dini, dan hal tersebut sejalan dengan penelitian (Arefaynie et al., 2020). Remaja perempuan yang tidak bersekolah lebih berisiko dibandingkan remaja perempuan yang bersekolah karena pendidikan yang didapatkan menjadi fungsi kedewasaan seiring dengan kemajuan tingkat pendidikan, dan mungkin juga karena paparan informasi dan edukasi mengenai topik tersebut (Turi et al., 2020). Remaja yang bersekolah yang semakin banyak mengetahui gejala, tanda dan bahayanya penyakit, maka semakin kecil kemungkinan melakukan inisiasi seksual dini yang merupakan perilaku seksual berisiko yang menjadikan seseorang rentan terhadap berbagai jenis penyakit menular seksual termasuk HIV/AIDS (Yosef et al., 2020). Selain itu, komunikasi dan pengawasan orang tua terhadap remaja mungkin cenderung lebih baik diantara remaja yang berpendidikan (Arefaynie et al., 2020).

Konsumsi alkohol memiliki hubungan bermakna dengan inisiasi seksual dini, dan hal tersebut sejalan dengan penelitian Rizkianti et al. (2020). Hal tersebut dimungkinkan karena minum alkohol dapat menurunkan pengendalian diri dan dapat menyebabkan remaja melakukan tindakan seksual dini dan aktivitas seksual berisiko lainnya (Turi et al., 2020).

Penggunaan narkoba memiliki hubungan bermakna dengan inisiasi seksual dini, dan hal tersebut sejalan dengan penelitian Yosef et al. (2020). Hal ini dimungkinkan karena sifat zat dari narkoba itu sendiri dapat mempengaruhi kesadaran individu dan pemikiran kritis mengenai risi- 
ko dan konsekuensi dari setiap perilakunya sehingga dapat menyebabkan inisiasi seksual dini yang tidak terduga (Arefaynie et al., 2020; Yosef et al., 2020). Penelitian menunjukkan bahwa remaja pengguna narkoba menunjukkan kelainan pada ukuran fungsi otak, yang terkait dengan perubahan neurokognisi dari waktu ke waktu yang terlihat pada volume struktur dan kualitas otak, dan aktivasi tugas kognitif (Song et al., 2019; Tapia-Rojas et al., 2018)

Merokok memiliki hubungan bermakna dengan inisiasi seksual dini, dan hal tersebut sejalan dengan penelitian Kassahun et al. (2019). Ada kemungkinan bahwa nikotin dapat meningkatkan fungsi dopamin sekaligus menurunkan fungsi serotonin. Jika demikian, merokok dapat menyebabkan peningkatan perilaku impulsif, yang dapat mencakup perilaku seksual. (Kopetz et al., 2018).

Komunikasi dengan orangtua tidak memiliki hubungan bermakna dengan inisiasi seksual dini, hal tersebut sejalan dengan penelitian Bizu et al. (2015). Hal ini dimungkinkan karena remaja cenderung lebih dekat dengan teman sebayanya dan jarang menghabiskan waktu dengan keluarga karena remaja ingin menjadi lebih mandiri. Sehingga diskusi yang terjadi mungkin kurang terbuka dan tidak berjalan efektif (Mulati \& Lestari, 2019). Namun di variabel yang berbeda, remaja yang memiliki pengawasan orang tua lebih kecil kemungkinannya untuk memulai inisiasi seksual dini dibandingkan dengan mereka yang tidak memiliki pengawasan orang tua (Bizu et al., 2015). Hal itu mungkin terjadi karena pengawasan orang tua yang efektif ter- hadap perilaku, sikap, dan nilai anak memiliki peran penting dalam mengurangi pengambilan keputusan yang buruk tentang kehidupan seksual dan reproduksi. Jadi bukan hanya sekedar dengan komunikasi saja (Kassahun et al., 2019).

Pengaruh teman sebaya memiliki hubungan bermakna dengan inisiasi seksual dini, dan hal tersebut sejalan dengan penelitian Kassahun et al. (2019). Remaja yang mendapat tekanan dari teman sebaya memiliki risiko 3,2 kali lebih tinggi untuk melakukan inisiasi seksual dini dibandingkan remaja yang tidak mendapat tekanan dari teman sebaya. Pada masa ini, hubungan antara orangtua dan remaja memang cenderung akan lebih sedikit dibandingkan dengan teman sebayanya. Seperti saudara kandung, teman adalah agen sosialisasi, yang menetapkan standar perilaku dan menjadi panutan, sehingga membentuk perkembangan sikap dan norma seksual. Pada masa perkembangan, teman sebaya berperan sangat penting karena dapat meningkatkan tekanan ke arah konformitas dalam kelompoknya. Hal tersebut yang dapat menghasilkan keinginan kuat bagi remaja untuk mengadopsi sikap dan norma teman sebayanya, salah satunya melakukan inisiasi seksual dini (Peçi, 2017).

Kepemilikan pacar memiliki hubungan bermakna dengan inisiasi seksual dini, dan hal tersebut sejalan dengan penelitian Gonçalves et al. (2019). Hal tersebut dimungkinkan karena remaja yang memiliki pacar dapat memulai berhubungan seks lebih awal karena pasangannya menginisiasi untuk melakukan hal tersebut tanpa kemauan mereka. Tempat tinggal 
tidak memiliki hubungan yang bermakna dengan inisiasi seksual dini, hal tersebut sejalan dengan penelitian Bizu, et al. (2015). Hal ini mungkin dikarenakan risiko remaja yang tinggal di pedesaan maupun di perkotaan kini sudah tidak jauh berbeda. Walaupun remaja perkotaan cenderung mendapat akses yang lebih mudah terkait informasi kesehatan seksual dan reproduksi, namun tidak selalu menjamin remaja mendapat informasi yang sehat. Hal tersebut bisa saja sebaliknya, seperti mudahnya mendapat akses konten negatif lainnya (Arefaynie et al., 2020).

Status ekonomi memiliki hubungan bermakna dengan inisiasi seksual dini, dan hal tersebut sejalan dengan penelitian Yakubu \& Salisu (2018), bahwa status ekonomi terbawah meningkatkan kemungkinan inisiasi seksual dini karena remaja perempuan dapat menggunakan praktek seksual sebagai sumber pendapatan. Paparan media memiliki hubungan bermakna dengan inisiasi seksual dini, dan hal tersebut sejalan dengan penelitian. Hal ini mungkin karena remaja yang terpapar media dapat memperoleh pengetahuan tentang konsekuensi dari inisiasi seksual dini sehingga menghindari mereka dari perilaku tersebut (Abate et al., 2020)

Program kespro dan seksual di sekolah, komunitas maupun tempat ramah remaja tidak memiliki hubungan yang bermakna dengan inisiasi seksual dini. Hal tersebut sejalan dengan penelitian yang dilakukan oleh (Arefaynie et al., 2020), bahwa tingkat pendidikan level komunitas remaja perempuan tidak memiliki hubungan dengan inisiasi seksual dini. Hal ini mung- kin dikarenakan pendidikan mengenai kesehatan reproduksi dan seksual yang diberikan belum komprehensif. Untuk berhasil menerapkan edukasi yang berkualitas, sekolah, komunitas, maupun pelayanan kesehatan memerlukan kebijakan yang mendukung, konten yang sesuai, staf terlatih, dan orang tua serta masyarakat yang terlibat (World Health Organization, 2020).

\section{KESIMPULAN}

Faktor yang berhubungan signifikan dengan inisiasi seksual dini mencakup usia, pendidikan, konsumsi alkohol, merokok, pengaruh teman sebaya, kepemilikan pacar, status ekonomi, dan paparan media. Pengaruh teman sebaya dan pendidikan menjadi faktor yang paling dominan berhubungan dengan inisiasi seksual dini pada remaja perempuan di Indonesia tahun 2017. Remaja perempuan yang mendapat pengaruh dari teman sebaya memiliki risiko 27,127 kali lebih besar untuk melakukan inisiasi seksual dini dibandingkan remaja perempuan yang tidak mendapat pengaruh dari teman sebaya. Sedangkan remaja perempuan yang tidak bersekolah memiliki risiko 10,909 kali lebih besar untuk melakukan inisiasi seksual dini dibandingkan remaja perempuan yang berpendidikan tinggi.

Penelitian menggunakan data sekunder SDKI 2017 dengan desain studi cross sectional. Sehingga penelitian ini memiliki keterbatasan tidak bisa menjelaskan hubungan sebab-akibat. Data SDKI 2017 tidak dapat memenuhi kebutuhan peneliti untuk melakukan penelitian terhadap salah satu variabel independen, yaitu 
variabel pengetahuan. Variabel tersebut tersedia dalam kuesioner namun dalam dataset tidak tersedia. Kemudian dalam SDKI 2017 terdapat missing data, dan peneliti tidak bisa melakukan pengecekan ulang terhadap data responden tersebut untuk dilengkapi. Oleh karena itu, peneliti mengatasinya dengan tidak mengikutsertakan responden yang tidak memiliki data yang lengkap terkait variabel penelitian. Kemudian keterbatasan lainnya adalah karena pengalaman hubungan seksual ini sifatnya sangat personal dan sensitif, maka kemungkinan adanya ketidakjujuran responden dalam menjawab pertanyaan.

Berdasarkan hasil penelitian, disarankan kepada Kementerian Pendidikan dan sekolah untuk dibuatnya mekanisme pendidikan kesehatan reproduksi dan seksual yang komprehensif baik di dalam maupun luar sekolah. Mengembangkan kurikulum nasional secara lebih formal dan lebih sistematis, dengan menyediakan misalnya, instruksi penilaian, metode pengajaran, konten yang relatif seragam, mengembangkan sistem pemantauan dan evaluasi khusus, dan memperkuat hubungan rujukan yang ada antara sekolah dan layanan ramah remaja. Program GenRe BKKBN dapat memanfaatkan media yang banyak digunakan kaum remaja seperti TikTok, stasiun radio Prambors, dan Twitter untuk membagikan edukasi agar terjangkau remaja yang lebih meluas; dan BKKBN perlu meningkatkan kinerja program GenRe Bina Keluarga Remaja (BKR) untuk membantu orang tua dalam mengoptimalkan perannya dalam mengawasi remaja.

\section{DAFTAR PUSTAKA}

Abate, B. B., Kassie, A. M., \& Kassaw, M. W. (2020). Prevalence and determinants of early initiation of sexual intercourse among youth girls in Ethiopia. Journal of pediatric nursing. http://doi.org/10.1016/ j.pedn.2020.06.008

Adamek, K., Meckstroth, A., Inanc, H., Ochoa, L., O'Neil, S., McDonald, K., \& Zaveri, H. Conceptual Models to Depict the Factors that Influence the Avoidance and Cessation of Sexual Risk Behaviors Among Youth (No. bbc3741c9fbe4963b6e053933f768528).

Mathematica Policy Research. https:// ideas.repec.org/p/mpr/mprres/ bbc3741c9fbe4963b6e053933f768528.html

Arefaynie, M., Yalew, M., Damtie, Y., \& Kefale, B. (2020). Determinants of early sexual initiation among female youth in Ethiopia: a multilevel analysis of 2016 Ethiopian Demographic and Health Survey. BMC women's health, 20(1), 1-8. https://doi.org/10.1186/ s12905-020-01069-4

Bizu, D., Aderaw, Z., \& Kassa, G. M. (2015). Assessment of early sexual initiation and associated factors among preparatory school students of FaggetaLekoma District, Awi Zone, Northwest Ethiopia, 2015. International Journal of Clinical Medicine, 6(08), 521. http://doi.org/10.4236/ ijcm.2015.68070

Citrariana, S., Paramawidhita, R. Y., Suryadini, H., Dawam, M., \& Awumistiko, A. (2021). Determinasi Kejadian Perilaku Seksual Pranikah dalam Aktivitas Pacaran Remaja di Kalimantan Tengah. Jurnal Surya Medika (JSM), 7(1), 39-47. https://doi.org/10.33084/ jsm.v7i1.2232

Dini, A. Y. R., \& Nurhelita, V. F. (2020). Hubungan Pengetahuan Remaja Putri Tentang Pendewasaan Usia Perkawinan Terhadap Risiko Pernikahan Usia Dini. Jurnal Kesehatan, 11 (1), 50-59. https://doi.org/10.38165/ jk.v11i1.197

Gonçalves, H., Soares, A. L. G., Bierhals, I. O., Machado, A. K., Fernandes, M. P., Hirschmann, R., \& Menezes, A. M. (2017). Age of sexual initiation and depression in adolescents: Data from the 1993 Pelotas (Brazil) Birth Cohort. Journal of affective disorders, 221, 259-266. https://doi.org/10.1016/ j.jad.2017.06.033 
Habito, C. M., Vaughan, C., \& Morgan, A. (2019). Adolescent sexual initiation and pregnancy: what more can be learned through further analysis of the demographic and health surveys in the Philippines?. BMC public health, 19(1), 1-13. http://doi.org/10.1186/ s12889-019-7451-4

Kassahun, E. A., Gelagay, A. A., Muche, A. A., Dessie, A. A., \& Kassie, B. A. (2019). Factors associated with early sexual initiation among preparatory and high school youths in Woldia town, northeast Ethiopia: a crosssectional study. BMC public health, 19(1), 1 -8. https://doi.org/10.1186/s12889-019-6682 $-8$

King, M. (2019). Stigma in psychiatry seen through the lens of sexuality and gender. BJPsych international, 16(4), 77-80. https:// doi.org/10.1192/bji.2019.12

Kopetz, C. E., Woerner, J. I., \& Briskin, J. L. (2018). Another look at impulsivity: Could impulsive behavior be strategic?. Social and Personality Psychology Compass, 12(5), e12385. https://doi.org/10.1111/spc3.12385

Lee, R. L. T., Yuen Loke, A., Hung, T. T. M., \& Sobel, H. (2018). A systematic review on identifying risk factors associated with early sexual debut and coerced sex among adolescents and young people in communities. Journal of clinical nursing, 27(3-4), 478-501. https://doi.org/10.1111/jocn.13933

Mohammadi, F., Kohan, S., Mostafavi, F., \& Gholami, A. (2016). The Stigma of Reproductive Health Services Utilization by Unmarried Women. Iranian Red Crescent Medical Journal, 18(3). http://doi.org/10.5812/ ircmj.24231

Mulati, D., \& Lestari, D. I. (2019). Hubungan Penggunaan Media Sosial Dan Pengaruh Teman Sebaya Dengan Perilaku Seksual Remaja. Jurnal Untuk Masyarakat Sehat (JUKMAS), 3(1), 24-34. http:// ejournal.urindo.ac.id/index.php/jukmas/ article/view/592

Peçi, B. (2017). Peer influence and adolescent sexual behavior trajectories: links to sexual initation. European Journal of Multidisciplinary Studies, 2(3), 96-105. http:// doi.org/10.26417/ejms.v4i3.p96-105

Pringle, J., Mills, K. L., McAteer, J., Jepson, R., Hogg, E., Anand, N., \& Blakemore, S. J.
(2017). The physiology of adolescent sexual behaviour: A systematic review. Cogent social sciences, 3(1), 1368858. http:// doi.org/10.1080/23311886.2017.1368858

Project SOAR (2021) Impulsiveness, Depression, Sexual Behavior, and Sexually Transmitted Infections and HIV-related Outcomes among Out-of-school Adolescent Girls and Young Women in Rural Southern Malawi. Washington DC.

Rizkianti, A., Maisya, I. B., Kusumawardani, N., Linhart, C., \& Pardosi, J. F. (2020). Sexual intercourse and its correlates among schoolaged adolescents in Indonesia: analysis of the 2015 Global School-based Health Survey. Journal of preventive medicine and public health, 53(5), 323. http:// doi.org/10.3961/JPMPH.20.028

Song, S., Zilverstand, A., Gui, W., Li, H. J., \& Zhou, X. (2019). Effects of single-session versus multi-session non-invasive brain stimulation on craving and consumption in individuals with drug addiction, eating disorders or obesity: A meta-analysis. Brain stimulation, 12 (3), 606-618. https://doi.org/10.1016/ j.brs.2018.12.975

Tapia-Rojas, C., Carvajal, F. J., Mira, R. G., Arce, C., Lerma-Cabrera, J. M., Orellana, J. A., \& Quintanilla, R. A. (2018). Adolescent binge alcohol exposure affects the brain function through mitochondrial impairment. Molecular neurobiology, 55(5), 44734491. https://doi.org/10.1007/s12035-0170613-4

Techasrivichien, T., Darawuttimaprakorn, N., Punpuing, S., Musumari, P. M., Lukhele, B. W., El-Saaidi, C., \& Kihara, M. (2016). Changes in sexual behavior and attitudes across generations and gender among a populationbased probability sample from an urbanizing province in Thailand. Archives of sexual behavior, 45(2), 367-382. http:// doi.org/10.1007/s10508-014-0429-5.

Turi, E., Merga, B. T., Fekadu, G., \& Abajobir, A. A. (2020). Why too soon? Early initiation of sexual intercourse among adolescent females in Ethiopia: evidence from 2016 Ethiopian Demographic and Health Survey. International journal of women's health, 12, 269. https://dx.doi.org/10.2147\% 2FIJWH.S244621

UNFPA (2017) Teenage Pregnancy and Early Mar- 
riage in Timor-Leste. https://planinternational.org/tpem-report

United Nations (2018) World Youth Report: Youth and the 2030 Agenda for Sustainable Development. New York.

World Health Organization \& UNFPA (2012) Preventing Early Pregnancy And Poor Reproductive Outcomes Among Adolescents In Developing Countries: What The Evidence Says.

World Health Organization (2017) Leaving no adolescent behind in health and development in Indonesia. https://www.who.int/life-course/ partners/innov8/indonesia-adolescents/en/
World Health Organization (2020) Adolescent Pregnancy. https://www.who.int/news-room/fact -sheets/detail/adolescent-pregnancy

Yakubu, I., \& Salisu, W. J. (2018). Determinants of adolescent pregnancy in sub-Saharan Africa: a systematic review. Reproductive health, 15 (1), 1-11. https://doi.org/10.1186/s12978018-0460-4

Yosef, T., Nigussie, T., Getachew, D., \& Tesfaye, M. (2020). Prevalence and Factors Associated with Early Sexual Initiation among College Students in Southwest Ethiopia. BioMed Research International, 2020. https://doi.org/10.1155/2020/8855276 